\title{
Aantekeninge/Notes
}

\section{Trade mark law: Can an unregistered mark be protected prior to the acquisition of a reputation?}

\section{Introduction}

It is generally accepted that a 'mere' trade application fixes the date of application, and not much else. Instead, the focus is on the two standard forms of protection which exist in relation to a trade mark. Firstly, a trade mark registration, which is arguably the most effective form of protection. Protection in terms of the Trade Marks Act (194 of 1993) is available immediately, on registration, and is not, in the short term, dependent on the use of the mark. The registration will also automatically extend across the country. Secondly, in the common law, the remedy of passing off exists. This remedy will only be available once a reputation has been established. It was clearly stated in Caterham Car Sales and Coachworks Ltd v Birkin Cars (Pty) Ltd (1998 ZASCA 44) that (par 20):

The correct question can be distilled from the judgments on passing-off of this Court mentioned earlier ... In general terms, it appears to me to be whether the plaintiff has, in a practical and business sense, a sufficient reputation amongst a substantial number of persons who are either clients or potential clients of his business (own emphasis).

Seemingly, then, where a simple trade mark application is at hand, it might be problematic to obtain protection for such a mark. A scenario that might seemingly fall outside the sphere of the above two standard forms of protection, is where a business has spent millions of rand to prepare to launch a new product, only to find that a competitor has launched a similar product under a confusingly similar name a day before. There is considerable confusion in the market. The business does not have a reputation in the market yet, neither a trade mark registration, and is seemingly without a remedy. Is the money spent wasted? The unfairness of the situation is apparent. That being said, possible situations in which protection might be available are discussed below.

\section{The Trade Marks Act}

Upon registration, the proprietor of a registered mark is often perceived to have 'per se' rights. The concept 'per se' is used to indicate rights flowing from mere registration, whether there has been use of the mark or not (see Webster \& Page South African Law of Trade Marks (1997)

How to cite: Alberts 'Trade mark law: Can an unregistered mark be protected prior to the acquisition of a http://dx doi.org/10 17159/2225-7160/2015/v48n2a9 
12-79). The authors state this when discussing section 36(1) of the Trade Marks Act, which protects a party that has used its mark prior to the earliest of the proprietor's date of first use or date of filing. In relation to this provision, the following was stated (without crediting said authors) in Nino's Italian Coffee \& Sandwich Bar CC v Nino's Coffee Bar \& Restaurant CC (1998 3 SA 656 (C) 675H):

The underlying purpose of this section is to prevent a proprietor of a trade mark from exercising his rights merely on the basis of priority of registration and it preserves whatever common-law rights there may be antecedent to the rights of the registered proprietor.

Here the earlier user, A, is accordingly protected because the fact that $B$ was the first to file should not be decisive. B was first to file, but A was first to use. If the mark of $B$ is registered, A could rely on section 10(12) to have B's mark expunged. Section 10(12) protects common law rights but presupposes the existence of a reputation, which does not solve the problem under discussion. Are other perspectives possible?

The current Trade Marks Act seemingly accords a greater measure of deference to applications than the previous Trade Marks Act (62 of 1963; 'previous Act')) did. Under the current Act, there can be grounds of opposition. Under section 17(3) of the previous Act, a determination of rights procedure was created. Turning to substantive law in the latter regard, it was said in Victoria's Secret Inc v Edgars Stores Ltd (1994 (3) SA 739 (A) that (parr 752D-E)):

In determining which of competing claimants should prevail, the guiding principle is encapsulated in the maxim qui prior est tempore potior est jure: he has the better title who was first in point of time. In the Moorgate judgment Mr Trollip said:

In a situation in which competing applications for the registration of the same or similar marks are filed in the R.S.A. the general rule is that, all else being equal, the application prior in point of time of filing should prevail and be entitled to proceed to registration. In a 'quarrel' of that kind 'blessed is he who gets his blow in first.

The first statement by Trollip J would seem to be clearly correct if one is dealing with two parties who have simply filed applications, and no use is sought to be proven. However, the statement would of course have to be tempered if one of the parties had use that predated the other's date of application. In line with this proposition, it was considered relevant in the Victoria's Secret case whether a reputation existed, with the implication that use can influence the priority of rights (par 48).

The current Act makes reference to applications in an opposition context in two instances. First, section 10(15) determines that, subject to sections 14(1) - honest concurrent use applications - and, second, in terms of section 10(16), one may oppose a later conflicting application on the basis of an earlier application. Section 10(15) seems to deal with conflicting applications' dates only, which would involve a somewhat 
mechanical approach. Filing dates are simply compared. This provision typically envisages a situation where a later application, filed by $\mathrm{X}$, is opposed by $Y$, a person having an earlier application date. However, it might be that $X$ has use predating that of $Y$, or $Y$ might not have any use. In such an instance, looking solely from the perspective of section 10(15), $\mathrm{X}$ should be able to successfully defend the opposition by Y. X may also rely, instead, on section 14(1) which allows for an application to be filed on the basis of honest concurrent use. If $X$ decides to pursue the opposition of Y's application, he would have to qualify in terms of section 10(16). This enactment allows for an opposition of an earlier application by the owner of a later application that has 'existing rights'.

In this situation $\mathrm{X}$, the later applicant, is enabled to oppose the earlier application by $\mathrm{Y}$ and would carry the burden of proof (Webster 'The Registration of Trade Marks' in Visser (ed) The New Law of Trade Marks and Designs 17). The basis on which the prima facie superiority of the earlier application can be overcome is the concept existing rights'. The view of Webster and Page (supra 6-38) is that 'existing rights' could include use of a mark to an extent that would not be sufficient for an opposition under section 10(12), protecting common law rights, but which, nevertheless, establishes that registration would be contrary to the rights built up. From this it would follow that the mere filing of an application ensures a lighter burden of proof. 'Existing rights' would seem to be a less involved process than proving the existence of a reputation (s 10(12)). For example, some preliminary marketing activities relating to a product not yet on the market, could be significant.

\section{Unregistered Marks in terms of the Trade Marks Act}

For the sake of comprehensiveness, it must be pointed out that section 35(3) of the current Act allows for an infringement action against the use of a well-known (often) unregistered mark. Similarly, provision is made for an opposition in similar circumstances (s 10(6)). Section 35(3) could however be problematic as a basis of protection for litigious proceedings instituted by a business that has not yet established a reputation. Regard must, here, be given to the ruling in McDonald's Corporation $v$ Joburgers Drive-Inn Restaurant (Pty) Ltd and Another; McDonald's Corporation v Dax Prop CC and Another; McDonald's Corporation $v$ Joburgers Drive-Inn Restaurant (Pty) Ltd and Another (1996 ZASCA 82). In this case, it was held that (par 36-37) 'I consider therefore that a mark is well-known in the Republic if it is well-known to persons interested in the goods or services to which the mark relates' (parr 36-37). This 'well-known' requirement could exclude protection in the situation under discussion where there is no reputation. 


\section{$4 \quad$ Legislation Acknowledging 'mere' Trade Mark Applications}

\section{Consumer Protection Act}

Certain legislative instruments acknowledge mere applications. The Consumer Protection Act (68 of 2008; 'CPA') regulates the operation of businesses by creating a system of compulsory registration (s 79(1) of the CPA). Business names registered in terms of the CPA are open to objection on a number of grounds. It is specifically determined that an objection can be based on a registered trade mark, or a mark in respect of which an application has been filed in the Republic for registration as a trade mark. 'Trade mark' means a trade mark as defined in section 2(1) of the Trade Marks Act. Section 2(1) describes a mark in terms of its general distinguishing function and is not limited to registered marks in particular. Also included is a well-known trade mark as contemplated in section 35 of the Trade Marks Act (s 81(2)(a)(ii) of the CPA). Section 35 is of course a provision protecting well-known marks as envisaged in the Paris Convention for the Protection of Industrial Property of March 1883. In this case, there is accordingly protection even though no registration is (necessarily) involved. Lastly, section 81(2)((b)(i) could perhaps be seen as a 'statutory' form of the prohibition of passing off, as it proscribes misleading conduct etcetera.

\section{Companies Act}

A similar approach is followed by the Companies Act (71 of 2008) in section 11(2)(a)(iii). A name to be registered may not resemble a registered trade mark belonging to a person other than the company; or a mark in respect of which an application has been filed in the Republic for registration as a trade mark; or a well-known trade mark as contemplated in section 35 of the Trade Marks Act. As highlighted above, section 11(2)(b)(i) might be considered to be a 'statutory' form of the prohibition of passing off, as it proscribes the registration of misleading names.

\section{Counterfeit Goods Act}

The Counterfeit Goods Act (37 of 1997) seems to restrict protection to registered marks. This would follow from the definition of intellectual property right' in section 1(1) of the Counterfeit Goods Act which refers to the rights in respect of a trade mark conferred by the Trade Marks Act, and includes rights in relation to a trade mark as mentioned in section 35 of the Trade Marks Act. In contrast with the CPA and the Companies Act, which recognise applications, in the Counterfeit Goods Act the term 'rights' is seemingly restricted to registrations. In Aruba Construction (Pty) Ltd and Others $v$ Aruba Holdings (Pty) Ltd and Others (2000 2 SA 155 (C)) it was stated that (par 169): 
There are no - or insufficient - allegations in the papers before me to support a reliance by the applicants on common-law trade mark rights of the kind envisaged in s 33 of the Act, and an order based on statutory trade mark infringement cannot be obtained in respect of a trade mark which has been applied for but not yet registered ... (own emphasis).

Incidentally, the reference to section 33 of the Trade Marks Act is incorrect in the sense that section 33 does not grant a substantive common law remedy. It merely states that a person can choose between a common law or statutory infringement action.

\section{Is it only Registration that is Affected?}

It may be that not only is registration affected, but use as well. One must, here, have regard to the issue of context and indirect consequence. For instance, an objection to a proposed business name can be lodged on the basis of a company name in terms of section 81(2)(a)(i) of the CPA. The outcome of successful objection proceedings would, in the final analysis, be that the proposed business name cannot be used (s 79(3) of the CPA).

\section{Domain Names}

The Electronic Communications and Transactions Act (25 of 2000) regulates the registration of domain names. Regulations dealing with objections to domain names were issued on 22 November 2006 under Notice R 1166 in Government Gazette 29405 (available at http:// www.domaindisputes.co.za). The first ground on which a complaint in terms of the Regulations can be based, is that the registration is abusive (reg 3(1)(a) of GG 29405 supra). This concept means that a domain name was either registered or acquired in a manner which, at the time of registration, took unfair advantage of or was unfairly detrimental to the complainant's rights, or has been used in a manner that takes unfair advantage of, or is unfairly detrimental to the complainant's rights (reg 1 of GG 29405 supra). The latter term include[s] intellectual property rights, commercial, cultural, linguistic, religious and personal rights protected under South African law, but is not limited thereto' (reg 1 of GG 29405 supra).

A second ground is that a domain name is offensive; that is, it advocates hatred that is based on race, ethnicity, gender or religion and/ or constitutes incitement to cause harm (reg 4(2) of GG 29405 supra). The question that arises here is the meaning of the term 'intellectual property right'. Obviously, a trade mark registration would be included, as well as a mark that has been used extensively. However, would a trade mark application suffice? The decision in mrplastic.co.za (ZA2007-0001, judgement by $\mathrm{OH}$ Dean, dated 7 June 2007 (available at http:// www.domaindisputes.co.za/downloads/cases/ZA2007-0001/ZA20070001 .pdf) might be analogous. It was stated that (par 4):

The Complainant in 1976 registered a company name 'Mr Plastic (Pty) Limited' and in 1991 it converted that company to a close corporation having 
the name 'Mr Plastic CC'. The registration of a company name or a close corporation name, per se, conferred upon the entity in question no rights in that name enforceable against third parties in the sense that third parties can be restricted from using it...

Similarly, in mixit.co.za (ZA 2008-0020, judgment of C Le Roux, dated 30 September 2008 (available at http://www.domaindisputes.co.za/ downloads/cases/ZA2008-0020/ZA2008-0020.pdf)) it was held that (par 5.2.1):

Against this background, since the Complainant's contention that it owns trade mark rights in connection with a trade mark which is the subject of pending South African trade mark applications is not recognised in law, the Adjudicator finds that the Complainant has not succeeded in showing trade mark rights on this basis. The Complainant's claims that it owns business name and domain name rights on the basis of the registration of its company name and the domain names are similarly rejected. A company or domain name registration does not in itself give rise to any rights (own emphasis).

Writing on this issue, Hurter (Aspects of the nature and online resolution of domain-name disputes (?LLD thesis 2011 UNISA) 228-229), points to a number of instances where recognition was not given, both locally and overseas, to mere trade mark applications. Hurter adopts the view that the owner of an application should either await registration, or rely on common law rights. In conclusion of this section, it would appear that a measure of protection does attach to a trade mark application. A business not having a reputation yet can, therefore, have some form of protection, but not in relation to a domain name or counterfeit scenario.

\section{Common Law}

The first issue that needs addressing here is whether a product must be on the market before protection for its mark can be obtained? In Stellenbosch Wine Trust Ltd v Oude Meester Group Ltd (1972 3 SA 152 (C)) it was argued that the product had, at the relevant time, not yet been marketed and that the label concerned had accordingly acquired no reputation $(159 \mathrm{H})$. However, passing off and unlawful competition was held to have taken place.

A reputation in some sectors of the market, but not amongst the general public, was held to suffice in Pepsico Inc $v$ United Tobacco Co Ltd (1988 2 SA 334 (WLD)). A introduced its product to the major retailers by way of advertisements and thereafter by advice and information to them in preparation for the marketing of the products. Factory equipment was purchased, which was used to make samples for testing for quality specifications. Thereafter the introduction of suitable packaging took place, as well as the development of an advertising strategy and sales merchandising which related to equipment for the presentation and sale of the product in retail outlets. Passing off was found (346B-D). The court stated (346B-D) the following: 
The question then is: has there been a launch to the trade, and were the applicants trading as such? And consequently, could there have been a passing off? In my view, the applicants have successfully proved the requisites for passing off, in that the trade had been approached, advised, demonstrated to, and arrangements made for the wholesale selling of the product. Samples had been provided; the marketing get-up of the packaging had been prepared and demonstrated. The form of marketing was not only demonstrated to all the major retailers who comprised between 30 and 40 percent of the snack food industry suppliers to the public, but arrangements had been made to take leading marketers from most of the larger retail suppliers overseas to increase their marketing knowledge and know-how for the specific purpose of the launch to the public, of the product concerned.

There was accordingly exposure to some sectors of the market. The court also made (346D-I, own emphasis) the following important statement:

As was stated in the Aristoc decision, trade is a wide word, and a connection with goods in the course of trade means an association with the goods in the course of their production and preparation for the market. Here, in my view, there has been such an association with the goods by the retailers to whom they were presented. The fact that the product had not gone through to the final consumer is, in my view, not a sine qua non for the purpose of entering the trade. In the event, the supplier ... is the retailer. It is not the man in the street or the little boy who buys the packet of chips at the corner café. That is another section of the market, and no doubt a very substantial, if not the greater part, of the market. However, the fact that it has not been launched and provided to the corner café does not derogate from the fact that the Ruffles chip, presented in the form in which it is to be finally launched ... has, in my view, entered the market. There had been discussion, arrangement for marketing; it has acquired through demonstration the same reputation which it enjoyed overseas. That reputation has become associated with the product in the preparation by all the parties concerned for the market, within the territorial area of the Republic of South Africa. The reference to the Carling case, in my view - and after consideration of the facts therein set out - makes it quite clear that that case is on the facts distinguishable from the facts in the present case. There, there had been no such preparation of the market and the retail market to whom the producer was going to sell. Here the position is clearly different.

It would seem that the court regarded preparations for the actual launch of the product as of significance. The end consumer was therefore not the only sector to be taken into consideration. A reputation can accordingly also exist "upstream" in the distribution and marketing structure. With regard to the existence of reputation as a requirement for passing off, the authors Van Heerden and Neethling Unlawful Competition (2008) 168 state that it is not necessary to prove that customers are acquainted with the mark, only that the connection between the goods and the mark enables customers to individualise and thus distinguish his goods from other such goods. From this it is said to follow that in the case of "fancy" or invented marks, a reputation is not required. The connection of such a name can only serve to individualise the goods, the name is in itself already distinctive (168). Van Heerden and Neethling 169 (emphasis in 
original) is critical of the Oude Meester ruling, stating that a finding of passing off was incorrect, as:

It is, however, doubtful whether this is a case of passing off in its traditional sense. As a matter of fact, the applicant could not acquire a right to the label as distinctive mark before his wine was marketed, since the label did not have any distinguishing value at that stage. The label would only have individuated the wine - in other words, enabled customers to distinguish the wine from other wines - when it was placed on the market. Accordingly, the respondent could not have created the misrepresentation that his wine was the wine of the applicant; passing off his wine as that of the applicant was therefore out of the question.

These views, requiring placement on the market, would seem to be in conflict to an extent with those of the authors regarding fancy marks referred to above, namely that for such marks a reputation is not necessary. Another facet is that in their discussion of the right to a distinctive mark, the authors point out that the right to a distinctive mark is an accessory right to the right to goodwill (113). Moreover, there is overwhelming authority for the requirement of a reputation. In practical terms, a mark still existing only within the confines of a company cannot provide rights, if the right to the mark is seen as an accessory right. Here the question of a right to a trade secret, for instance, might feature.

Reference can also be made to the views of Gardiner The legal nature of the right to a trade mark in South African Law LLD-thesis Unisa (1995). Gardiner states (556) that for a subjective right of property to vest in a trade mark at common law, three elements are required. The claimant must adopt the mark, it must be distinctive, and, importantly, it must be used. It thus appears that the legal position would be that even if a right to a distinctive mark itself is advanced, the requirement of use is still applicable. It is also, arguably, a blurring of the doctrinal dividing line between common law and statutory protection. The Trade Marks Act specifically allows registration without use, and this approach should be limited to the statutory framework, and those that proceed to file an application. Lastly, the motive for bringing forward a business' launching of a product thereby sabotaging the rival's launch, can also be relevant, and provide "early" protection for the other party's mark (see Kellogg Company v Bokomo Co-operative Limited 19972 SA 725 (C) 739E). One is then dealing though with the issue of mala fides, a legal principle with a very broad sphere of application.

\section{Advertising Standards Authority}

If an unregistered trade mark has featured in an advertisement, the rules of the Advertising Standards Authority (ASA) might be relevant (http:// www.asasa.org.za/Default.aspx?mnu_id=37). Rule 9.1, dealing with imitation, provides that an advertiser should not copy an "existing advertisement, local or international, or any part thereof in a manner that is recognizable or clearly evokes the existing concept and which may result in the likely loss of potential advertising value." Importantly, this 
will apply notwithstanding the fact that there is no likelihood of confusion or deception or that the existing concept has not been generally exposed. Rule 9.2 determines that in considering international campaigns, consideration will be given to, inter alia, the undue imitation thereof by local advertisers. The condition is, however, that the advertiser must be committed to start trading in the local market within a reasonable period of time. This provision could thus provide protection where a trade mark has appeared in an advertisement, also overseas.

\section{Conclusion}

It appears that although use of a scope not amounting to the existence of a reputation does not provide extensive rights, there are certain contexts in which protection might be possible nevertheless. In statutory law, certain rights are given in terms of the Trade Marks Act. Then, again, the CPA grants protection, also in the form of a statutory type of prohibition of passing off. This might be relevant to the business not yet fully in the market. Similar provisions are found in the Companies Act. Lastly it was noted that the ASA Code might be effective, even if the particular advertisement was shown overseas. In conclusion therefore, there are some rights that attach to a trade mark application, or a trade mark the subject of an application, and the picture is not as bleak as it might seem at first.

W ALBERTS

University of Johannesburg 